\title{
Academic workload: the silent barrier to the implementation of technology-enhanced learning strategies in higher education
}

Mary Sarah-Jane Gregorya* and Jason Michael Lodgeb

aSchool of Natural Sciences, Nathan Campus, Griffith University, Brisbane, QLD, Australia;

bScience of Learning Research Centre, Centre for the Study of Higher Education, Melbourne

Graduate School of Education, The University of Melbourne, Melbourne, VIC, Australia

(Received 31 October 2014; final version received 16 March 2015)

The effect of technology-enhanced learning (TEL) strategies in higher education has arguably been transformative despite the not-insignificant barriers existing in this context. Throughout the discourse very little attention has been paid to those primarily responsible for this implementation-academic teaching staff. This paper aims to highlight the impact of academic workload allocations, an often silent barrier to the uptake of TEL strategies in higher education. We will discuss the effects of academic identity and culture, preferential time allocation to associative activities, academic technological capacity, university policies and workload and funding models on the uptake, and implementation on TEL in higher education. Our aim is to highlight the risks to staff, students and institutions should these concerns not be addressed and to propose a model for utilisation by all staff responsible for implementing flexible workload models supportive of further implementation of TEL strategies across the sector.

Keywords: academic identity; academic workload; blended learning; technology enhanced learning (TEL); online learning; workload allocation model (WAM)

\section{INTRODUCTION}

The exponentially escalating incorporation of technology-enhanced learning (TEL) in higher education over the past decade has implications on many different levels within higher education institutions and beyond (Goodyear \& Ellis, 2008; Kirkwood \& Price, 2014; Laurillard, Oliver, Wasson, \& Hoppe, 2009; Price \& Kirkwood, 2010; Tynan, Ryan, Hinton, \& Lamont Mills, 2012). Where distance education was previously a sector unto its own, it now utilises many TEL activities. Blended and online learning within this context can and has been defined in multiple ways, for example, e-learning, online delivery, mixed mode offering, flexible delivery or distance education. The range of activities involved in TEL can encompass the basic implementation of a learning management system (LMS), to individual activities that utilise a specific technology, to flexible course delivery with whole online course offerings through distance education and massive open online courses and everything in between. This confusion in terms and explosion in use of technology in higher education suggests that blended and online delivery of higher education programs is growing at a greater pace than the current understanding of the implications of this trend.

Overall, the fact that TEL is not necessarily understood or applied uniformly by those in the higher education sector has resulted in a mixture of definitions and understandings (Laurillard et al., 
2009; Oliver \& Trigwell, 2005). For the purposes of the following discussion, the definition of TEL by Goodyear and Retalis (2010) will encompass any educational situation where technology is being utilised to help people learn. TEL, in all its iterations in higher education, remains driven by three key factors (James, Krause, \& Jennings, 2010; Walker, Voce, \& Ahmed, 2012; Walker et al., 2014), being enhancing the quality of learning and teaching, meeting student expectations and improving access to learning for students off campus in any context, and thus these three factors have become a market driven cultural norm. The research evidence is conflicting as to the specific benefits of TEL, which can affect both student experience and learning outcomes (Goodyear \& Ellis, 2008; Harvey \& Williams, 2010; Mellar \& Jara, 2009; Quentin-Baxter, Kelly, Probert, MacMahon, \& Ferrell, 2008; Russell, 2001). A growing body of work indicating a combination of both online and face-to-face environments provides a positive student experience with better academic outcomes for students (Aldridge, 2013; Means, Toyama, Murphy, Bakia, \& Jones, 2009; Paechter, Maier, \& Macher, 2010). Some of the described benefits of the TEL component include enhanced engagement, flexible learning, long distance collaboration, asynchronous communication, time management skills, generic attributes, enhanced pedagogical practice and in some instances enhanced learning outcomes (Clark, 2011; González, 2010; Laurillard, 2007). Yet, in all the current discourse in the literature very little focus has been placed on those primarily responsible for the development and implementation of pedagogically sound, quality TEL practices that engage and benefit our students' learning outcomes - that is, the academic (faculty) staff.

Here we will explore what the impacts and implications of this brave new world of tertiary education may have on the higher education teaching fraternity, how difficulties could arise, without the support of implemented university priority and policy, coupled with changes in academic identity. There have been numerous identified barriers to the uptake of effective practice for TEL by tertiary institution teaching staff. These include cost, intellectual property issues, custom and practice, preconceptions and perceptions (Tynan et al., 2012; Walker et al., 2014). The top four most significant of these have longitudinally remained time, lack of academic staff knowledge, lack of funding and university and/or department culture (Walker et al., 2012; Walker et al., 2014). In addition to these barriers, the intrinsic and extrinsic drivers of TEL implementation vary considerably between institutions (Fleck, 2012). However, there is a distinct lack of discussion around a perhaps more insidious but critical element, which is potentially a silent barrier to the ubiquitous implementation of effective practice in TEL in tertiary education; that is, academic workload allocation. The aim of this critique is to add to the existing literature by exploring the impact of TEL, academic workload, quality learning experiences and university priorities and to then suggest a strategy that could support the discussion of better workload allocation associated with implementing TEL strategies.

So, why should TEL be accounted for in workload allocation models (WAMs)? At all levels of higher education there exists evidence to support the embedding of TEL (Tynan et al., 2012). To remain economically viable in the twenty-first century, institutions must consider its incorporation 
(Reushle, McDonald, \& Postle, 2009). For students, evidence suggests that the use of TEL has the capacity to enhance the overall student experience, promote collaborative behaviours and produce good learning outcomes (Clark, 2011; Diaz \& Brown, 2010); that is, provided the TEL experiences are pedagogically sound, appropriately developed and implemented, administratively supported and provided they ultimately provide quality learning experiences. The larger majority of students entering higher education in the twenty-first century are proficient with, and expect, some element of TEL in their higher education experience (James et al., 2010; Prensky, 2001) that extends beyond the simple use of an LMS such as Blackboard ${ }^{m}$, , WebCTтм or Моodleтм. Therefore, there exists an impetus for academics to ensure not only their technological capacity to implement TEL strategies but also their capacity for pedagogical, aligned curriculum in this arena. For academics, the shift away from the didactic sage on the stage paradigm to the guide on the side facilitating learning (King, 1993) is well supported by TEL and in some respects is reliant on it. Empirical evidence indicates that the development and short- to mid-term implementation of TEL is liable to increase workload initially but may ultimately alleviate workload requirements (Benson, Anderson, \& Ooms, 2011; Dowdle, 2004; McIntyre, Watson, \& Larsen, 2009; Vaughan, 2007). Yet the necessity of TEL in higher education seems paramount to ensure the best possible student experience and learning outcomes in the modern era with its incorporation in higher education necessary to meet student expectations (Paechter et al., 2010; Quigley, 2011).

Having established the need and importance of TEL in higher education, the questions pertaining to the impact on academic workloads include: How does TEL affect academic perceptions of their educational work? What evidence exists regarding the effect of TEL on academic time requirements? What are the barriers to the implementation of TEL that directly impact academic workload? What are the implications of these impacts?

Cultural change with regards to implementing TEL strategies involves all levels of the university and thus needs to be a concerted and collaborative effort. The fundamental nature of this change encompasses not only academics who have traditionally been responsible for development of course materials, but also various other teaching staff such as casual and short-term contract staff within institutions. This is in addition to resources and support mechanisms for the development and implementation of pedagogically appropriate TEL strategies that can only occur with strategic and supportive institutional leadership. This cultural change needs to occur in two levels-academic identity and WAMs.

\section{Challenges to academic identity associated with workload}

TEL challenges a long-term embedded culture of academia where traditional teaching practices influence everything from curriculum and assessment requirements to funding requirements and career rewards (Laurillard, 2007; Vaughan, 2007). Quigley (2011, p. 2) described the academic identity as "a constantly shifting target, which differs for each individual academic". 
Academic identity tends to be firmly associated far more with discipline research interests than educational address due to the nature of university hiring strategies that require higher degrees in discipline research but infrequently associated with formal educational training. Yet there are areas of commonality specific to professional disciplines. Academic identity also relies on the interaction between individuals, their disciplines and the universities where that identity was formed (Australian Council for Educational Research, 2011; Henkel, 2005). Furthermore, with the modern, rapid accessibility of knowledge now ubiquitous, academic identity is being further challenged whereby the academic role is more around facilitating the development of critical thinking, strategic planning and collegial problem-solving rather than the distributers of knowledge. Together this leads to challenging traditional academic workload models based primarily around previous distribution models. Thus, the impact of academic identity on workload expectations can also be variable.

\section{Academic value of TEL approaches}

Traditionally, scholarship in teaching and learning has been undervalued in higher education when compared with discipline-specific research agendas (Boitshwarelo, 2009). In the United Kingdom, faculty report that development and application of innovative TEL approaches increased their workload and were "frequently undervalued by management in comparison to $\cdots$ academic research". (Dowdle, 2004, p. 2) This sentiment is not unique to the UK, with Chalmers (2011) identifying valorisation of discipline research over teaching activities to be a "direct threat to quality student learning outcomes" (Tynan et al., 2012, p. 13) in Australia. Since TEL falls within the teaching and learning arena of higher education and not under discipline research for the majority of higher education academics, the value of research is often questioned by other discipline areas such as the pure sciences (Gormally, Evans, \& Brickman, 2014; Harvey \& Williams, 2010).

As a consequence of the greater incentive to focus on research over teaching, there is less value placed on teaching and evidence of scepticism about the increased use of technology in a teaching context. For example, academic perceptions of how technology is detrimental to the university education system can be drawn from many different sources. It is not uncommon for academics to have views such as "the use of LMSs could make students lazy" (Benson et al., 2011, p. 149) with less onus on students to find their own way. There are also the concerns around the diverse nature of disruptive technologies such as Wikipedia and YouTube (Tynan et al., 2012) and the negative impact these can have on student ways of research and learning (Laurillard et al., 2009). There are perceptions that traditional face-to-face methods work well and are not transferable to online offerings (Bleffert-Schmidt, 2011, p. 93) and thus they create an unnecessary workload to develop these components (McIntyre et al., 2009). Also, that online and distance education options are a poor second choice to face-to-face interactions (Fleck, 2012). Some academics also perceive TEL 
as threatening their ability to provide evidence of their established teaching capacities (Anderson, 2012), and common misconceptions include the perception that "e-learning will decrease academic workload or render staff redundant" (Sheehy, Marcus, Costa, \& Taylor, 2006, p. 4) when in reality academics are unsure that the time devoted to preparing TEL activities is sufficient to produce quality student learning outcomes (Tynan et al., 2012).

These academic staff scepticisms and misunderstandings are outdated and may stem from a lack of understanding of the pedagogy associated with TEL (Ooms, Burke, \& Linsey, 2008), conflict with traditional academic identity associated with higher education delivery (Cuban, 2001; Quigley, 2011) and a lack of technological capacity (McIntyre et al., 2009). In addition, Gosper et al. (2010) reported that only $54 \%$ of Australian academics believe that the introduction of TEL into universities has a positive impact on student learning. In conjunction, Russell's (2001) indexed research bibliography covering 355 research reports, summaries and papers reported no significant differences in student learning or outcomes in TEL versus traditional modes of instruction although he does highlight the difference between this finding and positive student gains from course redesign that effectively adapts content while incorporating TEL. Unfortunately, these perceptions are supported by global higher education sector resistance to the changing face of academic identity with relation to TEL. These issues can also be compounded in some instances by demographic factors. For example, in Australia, the challenge to academic identity is further exacerbated by an ageing academic population (Hugo, 2008). A combination of factors therefore contributes to negative perceptions of the use of TEL in institutions that is complicated by threats to traditional notions of academic identity.

\section{Impact of changing university focus on academic identity}

The ethos of change to a client-based business operative rather than a place of higher learning in tertiary education alone leads to discussions on how new public managerialism is an extrinsic driver (Quigley, 2011). Yet there exists vast complexity as to attribution of cost relative to TEL delivery (Tynan et al., 2012). Academic staff have been shown to exhibit "a deep-seated antipathy to a market ethos that reduces higher education to a narrow economic function" (Winter \& O'Donohue, 2012, p. 340). However, this change is also being driven by other external influences such as commercial LMS vendors and government funding models (Tynan et al., 2012) and will ultimately require the alteration to academic identity development with regards to the nature and purpose of higher education where TEL is a market-driven operative.

With content development a key component of academic work and thus identity, intellectual property rights are also a key facet of identity. Yet it has been identified by Fleck (2012) as one of the grey space areas that are a significant barrier to the implementation of TEL practices (Diaz \& Brown, 2010). Academic identity revolves around knowledge transmission and the sense of ownership of 
course materials developed despite these actually belonging to the university who employed the staff member. Laurillard et al. (2009) advocated the importance of this sense of ownership, but with the complexity of TEL this becomes much more a collaborative effort rather than individual development, thus again challenging traditional academic course development methodologies. The impetus to utilise workload allocation to TEL initiatives may be lost when intellectual property rights becomes cloudy.

\section{Effect of TEL on workload time management}

The brave new world of incorporating TEL into tertiary education practices requires the allocation of time to develop skills and resources. Many academics need to enhance their technological capacity with professional development in specific areas. To effectively address this, academics may require allocation of additional time to develop, implement, evaluate and review TEL initiatives, and there is a need to positively incentivise this process appropriately. This is particularly the case, though not exclusively, with the ageing Australian academic population (Hugo, 2008). This population has been described by Perlmutter (2011) to have less confidence, capacity and desire to implement TEL strategies than younger colleagues.

\section{Need for allocated time to up-skill technological capacity}

The development and implementation of TEL technologies on academic workload can be quite variable and is appreciably affected by the technological capacity of individual academics. What one staff member can achieve in a short timeframe may take much longer for a less technologically or pedagogically savvy member, but this should not be a significant prohibitive hurdle inhibiting these staff from engaging with TEL. This can become a major barrier to the incorporation of technology into teaching practice where academics perceive elements to be too time-consuming (Benson, 2011; Partridge, Ponting, \& McCay, 2011; Vaughan, 2007) without university recognition of the support and time required (Matheos, 2010) for best practices to be applied.

Most academic staff that utilise TEL approaches do so to engage students by enhancing interactivity and interest in the classroom, whether this be in face-to-face, mixed mode or distance scenarios, thereby providing support for different ways of learning (Benson, 2011; Dowdle, 2004). Staff members who engaged with TEL activities have been reported to fall into different groups for whom technological capacity was variable. One group comprised of experts, who might be characterised as lone rangers (Bates, 2000), spent considerable time and effort experimenting with classroom technology but sometimes required support to implement activities into large classes (Cavalli, Gnudi, Iovino, Lorenzi, \& Malvisi, 2007) though often doing so outside of recognised load allocations by virtue of their goodwill (McNickle \& Cameron, 2003). A second group comprised those who only used technology as a repository for information. A third group of novices were enthusiastic but required significant support to enhance their technological capacity for implementation of blended learning and thus could expect an elevated workload to temper their enthusiasm (Cavalli et 
al., 2007). For those academics who may be considered "late adopters" of TEL practices, there is definitely a need for "encouragement and targeted staff development to engage with the quality teaching opportunities that e-learning offers" (Sheehy et al., 2006, p. 757).

Support for the professional development of faculty capacity by universities is frequently highlighted as a key factor to ensure appropriate management of academic workloads (Graham \& Dziuban, 2008; Kirkwood \& Price, 2014; Laurillard et al., 2009; Ocak, 2010; Samarawickrema \& Stacey, 2007; Tynan et al., 2012). Thus, inherently, necessary professional development means additional workload (both time and effort) for academics who wish to utilise TEL strategies. This need is both a hidden impact on staff workload and a partially hidden cost to institutions (Sappey \& Relf, 2010, p. 5). There are several different models of implementing TEL approaches that have been described particularly for this final group, such as the Hartman and Truman-Davis (2001) "boutique approach", Bates's (2004) "collegial materials development model", and the "project management approach" (Bates, 2004; Ooms et al., 2008), and that can be used to support these academics. However, all these models infer significant additional work to up-skill those requiring support.

Examples where staff have been empowered to enhance their technological capacities or where educational design and support for TEL projects occurs and are acknowledged as part of academic workload have been shown to lead to both high uptake and relevant alignment of student learning outcomes, graduate attributes and overall positive experience for both staff and students (Clark, 2011; Sheehy et al., 2006). These practices have also been shown to improve student learning and enable transference of knowledge and skills, as described, for example, in Biggs and Collins (1982) SOLO taxonomy. Practices that support these outcomes include shared leadership for engagement with TEL, authentic approaches, customised flexible and easy to use resources that utilise reflective practice (Sheehy et al., 2006).

\section{More time to develop TEL initiatives}

Other reports on the implementation of TEL indicate that the lack of consistency in cost parameters, development methodologies or identification and comparative pedagogical benefits of new technologies (Laurillard, 2007) may lead to individuals having to invest time in these discoveries - the consequence of which is increasing development time, which may not be recognised. The shift from traditional methodologies to TEL is not a simple cut and paste activity but requires development of alternative methodologies (Bleffert-Schmidt, 2011) and evaluative measures. Picciano and Dziuban (2007) have suggested that redevelopment time to ensure the application of appropriate pedagogy and good practice should be at least 6 months in advance. Lack of development time may lead to activities being conducted for the sake of using technology rather than for wellaligned pedagogical enhancement. 
Rumble (2011) implied that while front-ending of workload is higher for TEL courses, redevelopment may not be required for 8-10 years, thus leading to an overall reduction in staff time. This is when compared to the similar traditional timeframe for print-based UK Open University courses. For example, TEL strategies provide opportunities to utilise well-developed resources to support discipline core concept delivery. Thus, only staff time is required to appropriately contextualise these for teaching efficacy within programs. The long-term benefits of this cannot be discounted (Tynan et al., 2012). However, there appears to be no additional evidence in the peerreviewed literature in recent decades to support this view.

\section{More time to implement TEL strategies}

One of the few positive responses reported in the literature regarding the impact of TEL strategies comes from Hartman, Dziuban, and Moskal (2000), where self-reporting from faculty staff cited the belief that efficiency and convenience would be enhanced in addition to student learning. However, its use does not inherently correlate with a reduction in contact time with students $\left(0^{\prime}\right.$ Connor, Mortimer, \& Bond, 2011), and the push for more material to be available online is additional load to that already allocated (Bates, 2004b). Ocak (2010) also reported that 95\% of faculty respondents felt that using TEL strategies required more time and effort than either face-to-face or purely online teaching but the benefits to student learning are worth the incurred additional workload (Starenko, Vignare, \& Humbert, 2007). Partridge et al. (2011) also provided a thorough synopsis of the many personal, pedagogical and university-wide benefits to be gained, but recognised challenges around a variety of time-associated impacts to implementing TEL strategies. Furthermore, QuentinBaxter et al. (2008) reported that in many instances the break-even time for TEL research and development is a minimum of 3 years alone for effective return on investment and value for money.

It would seem that the time spent implementing TEL activities is highly variable. Elevated workloads are reported to be frequently associated with activities such as discussion/bulletin boards and online consultation, with a general need for more student-teacher interactions in online courses to maintain authenticity (Ko \& Rossen, 2004; Sellani \& Harrington, 2002). Yet the creation of a strong social presence for online interactions is invaluable. Academics report that students perceived them to be more approachable and available although the amount of time associated with this type of activity was more than traditional office hours (Singleton, 2012). Scant reports exist where TEL activities reduce implementation workload. One of the few reported cases was when technological alternatives for elements of course-work such as quiz assessment reduced marking staff workload and the concurrent provision of rapid, timely feedback to students (Bath \& Bourke, 2010). Unfortunately, Laurillard et al. (2009, p. 292) noted that with university agendas pushing towards both "outcomes-oriented funding or accountability regimes" the 
time and headspace for effective development, implementation and reflection of TEL activities can become undermined.

\section{Lack of incentives to balance additional workload}

In this rapidly changing technological world it is important to not merely include TEL for the purpose of meeting policy requirements or expectation that students are digital natives (Prensky, 2001) and hence expect its inclusion. Ultimately this path is fraught with high risks to student, staff and university-wide outcomes, without appropriate considerations also being given to both pedagogical theory and instructional design. The inclusion of these elements, while critical for the success of TEL strategies, takes additional workload allocation.

These perceptions raise concerns around the lack of academic buy-in to develop such material that is impacted by staff technological capacity. Part of this can be attributed to the general lack of incentives, reward or recognition for innovative use or application of TEL (Bates, 2005; Chalmers, 2011; Wallace \& Young, 2010). This factor could inhibit those who would like advancement but lack the motivation to otherwise engage in development. Many authors suggest that implementation of university-level incentives are necessary to counterbalance disincentives of mastery time and incorporation of best pedagogical practice related to incorporating TEL strategies (Bates, 2004, 2005; Matheos, 2010; McIntyre et al., 2009; Schneckenberg, 2009; Wallace \& Young, 2010). There are many institutions and associated distance education providers, such as Open Universities Australia, who award best practice use of TEL and host regular forums on the subject. Unfortunately, some evidence demonstrates that incentives, such as national awards, appear not to be helpful in this particular area of scholarship (Chalmers, 2011). This could be important particularly when TEL initiatives are not specifically recognised or valued in other areas, such as workload documents or course development allocations (Matheos, 2010). Furthermore, incentivising schemes will most likely vary between institutions with practices and activities valued by one perhaps not being recognised by another, making transition between universities more difficult for academic staff. Incorporation of TEL expectations within university policy along with appropriate support mechanisms and WAMs, coupled with teaching expectations that include pedagogically appropriate TEL, are more likely to provide long term transferrable incentives, and was the second recommendation made in the Tynan et al.'s "Out of Hours" report (2012, p. 108).

\section{Is it worth investing more academic time?}

In the rapidly changing technology world it is important, not merely sufficient, to include TEL activities for the purpose of merely meeting policy requirements or practice expectations without appropriate considerations being given to the application of both pedagogical theory and instructional and assessment design. Although notional time is included for some level of curriculum design in WAMs, perhaps there is a need for a more specific or negotiated evaluation. 


\section{Risks to staff and students if more time is not invested}

The risks associated with lack of time and technical competency or appropriate allocation of time to TEL activities will impact on all areas of Garrison, Anderson, and Archer's (2010) community of inquiry (COI) educational framework. Allocated academic time will impact primarily within the teaching presence sphere associated with curriculum presentation, assessment development and course setting. Yet it is clear that these elements impact on both social and cognitive presences, particularly in a TEL environment (Valenzuela, Fisher, Whale, \& Adapa, 2013).

If TEL practices are required to be implemented by staff who lack appropriate expertise or support, potentially leading to a decrease in product quality (Bates, 2004, 2005; Ocak, 2010), this could in turn result in poor student educational experiences associated with TEL. Undesirable learning outcomes could result because addressing this lack of expertise is highly dependent on academic capacity.

Academic experience and capacity should therefore be evaluated to ensure the delivery of high quality student outcomes from TEL experiences, and allocated time for professional development and support should then be incorporated into workload allocations. This should be an investment in future iterations of these TEL activities to ensure best possible learning outcomes for students and staff alike.

\section{Hidden workload-professional development not usually part of WAMs}

"Providing professional learning for academics is problematic. High workloads and pressures to increase research output result in time constraints for academics engaging in professional learning ". (Herrington et al., 2010, p. 423) Yet overall there is a clear need to ensure that academics are able to make informed decisions regarding the use of technology in higher education (Benson et al., 2011) as new tools become available, in addition to acknowledging and embedding time for specific elements associated with TEL-elements that differ from traditional allocations but are not yet commonly attributed in WAMs.

Since academic staff are often not required, nor seem to be held accountable, for participation in professional development in teaching and learning, any time spent engaged in these activities is not covered under any WAMs. Though there is some recognition by institutions that there is a requirement for professional development, recent findings (Walker et al., 2014) indicate that in the UK institutions have reduced funding allocations associated with the development of academic skills in TEL activities. Thus, professional development remains a hidden financial and workload component for many academics but particularly for those with a keen interest in TEL initiatives. Although for many academics these additional support and workload allocation may be necessary " he level of 
technical competence" does not have to be "a significant impediment to the implementation of elearning in the curriculum" (Sheehy et al., 2006, p. 761). Ultimately the use of sophisticated technology will never be a substitute for teaching quality or the quality of pedagogically appropriate instructional design.

With the need for some level of technical competency critical in today's higher education teaching space, most academic staff will want or need to participate in some form of TEL up-skilling. It is clear that apposite practices need to be developed in a sustainable manner that acknowledges the hidden workload impact of developing and supporting the combined pedagogical and technological capacities of academic staff.

\section{University policy contributions to hidden workload}

There is a gathering body of evidence that suggests that the lack of functional university policy can lead to increases in the workload for academic staff who choose to implement TEL experiences (Dowdle, 2004). Many authors report a need for the articulation of university values and norms, with an urgent need for policy modification an inherent element in managing academic workload expectations (McIntyre et al., 2009; Samarawickrema \& Stacey, 2007; Tynan et al., 2012; Vaughan, 2007; Wallace \& Young, 2010). Concerning is "that most Australian universities do not have centralised procedures or guidelines for allocating academic workload which take into account the specific activities associated with online or blended learning"(Tynan et al., 2012, p. 5). This is not dissimilar to other international institutions (Barrett \& Barrett, 2008) such as in the UK and USA. Although policy alone will not guarantee successful outcomes for TEL initiatives, without it there will exist less onus for acknowledgement of the real costs for development, implementation and support.

\section{University WAMs}

The various workload models that are employed at faculty level to determine academic workloads can be problematic when attempting to incorporate TEL. Models attribute load either on contact-hours-based, actual-hours-based or points model allocation (Vardi, 2009). The additional time spent developing and implementing TEL strategies for non-traditional modes of teaching are not readily allocated or accountable for in current WAMs (Wallace \& Young, 2010). The impact of flexible delivery modes on the teaching labour process (Laurillard, 2007) needs to be not only acknowledged but also incorporated into management WAMs in the future (Dowdle, 2004). An additional confounding factor is the lack of consistent WAMs within individual institutions (Vardi, 2009), and although the contact-hours-based model appears to be the most commonly applied, it "requires amendment to accommodate e-teaching" (Tynan et al., 2012, p. 17). 


\section{Risks associated with lack of university policy and alignment in WAMs}

The non-alignment between university policy, academic WAMs and the actual work required in the TEL space is of concern. TEL time spent includes planning, design, development, production and support in addition to overall curriculum planning and alignment (Laurillard, 2007). Furthermore, anecdotal findings support those of Lazarsfeld Jensen and Morgan (2009), who reported that academics work much longer hours than policy documents require, to uphold their own personal standards of scholarship and identity. They also found that three of the top five contributors to negative pressures of academic life were associated with workload calculations; a direct result of the implementation of educational technology and misalignment to load allocations. Further to this, Vardi (2009) also reported technology and offshore teaching in the top eight contributors to underestimation of the real time tasks took to complete. In the recent report by Tynan et al. (2012), concerns around staff understanding of workload models were also found to be limited and allocation associated with TEL activities poorly framed in policy. Thus, it is unsurprising to find significant dissatisfaction associated with the additional load due to TEL, yet academics will reluctantly accept the additional load to ensure high quality student outcomes. If universities are aware of this situation and do not address it, then questions of inequity and long-term sustainability must be raised.

In general, the lack of university-level TEL policies is most likely to encourage the frequent idiosyncratic approaches found in university practices (Garrison, 2003; Wallace \& Young, 2010). This will only encourage the often reported lone rangers' (Bates, 2000; Bredeson, 2003) implementation of TEL by those engaged and enthusiastic academics willing to sacrifice their work-life balance to ensure success in this area (McIntyre et al., 2009). The activity of lone rangers may lead to staff burnout, poor student feedback and reduction in further utilisation of blended learning (O'Connor et al., 2011), and is an unsustainable practice (Sappey \& Relf, 2010) directly related to the hidden nature of TEL strategies. In these circumstances, there also lies the risk that pedagogy may be overshadowed by academic personal interest in particular technologies (Benson et al., 2011). In addition, nonuniformity of TEL implementation policy expectations such as different weightings for similar assessment items may be confusing to students. These issues stem from a need for university cultural WAM changes with respect to the sustainable implementation of high quality TEL strategies.

\section{University-wide cultural change}

Overall, there needs to be a cultural change in university-wide transparency and wellcommunicated expectations with regards to financial investment in any form of TEL strategy, provision of training for all staff (at varying levels of depth and complexity), identification of TEL as a strategic priority (Bates, 2005; Ocak, 2010; Vaughan, 2007) and then the adoption of appropriate strategies at all levels of management within the organisation (Benson et al., 2011; Singleton, 2012). 
Traditionally, creating a cultural change is both a difficult and long-term process with academics providing strong resistance (Herrington et al., 2010). Boitshwarelo (2009) reported on the need for significant change with regard to the culture of TEL, particularly in the science academic tribe, where the value of discipline research is much higher than in teaching and learning due to funding models. However, with the shift in higher education teaching methodology to incorporate technology into teaching practice, coupled with the new corporate-style universities (Winter \& O'Donohue, 2012), it is an identity change that is critical in all disciplines, not only at the academic level.

The fluid and sometimes diverse nature of academic identity could be both a barrier and an enabler of cultural change. Acknowledgement and support universities will ultimately facilitate this process (Bredeson, 2003) leading to discourse around policy and practical changes (Winter \& O' Donohue, 2012) that will more efficiently support the change to university-wide policy and academic identity. This change in academic values associated with ways of doing will hopefully lead to the revelation and future address of specific workload issues and expectations associated with TEL in higher education and ultimately address current inequities.

Where institutions or faculties have included time allocation, general staff support, and research allocation for implementing TEL projects, there has been much success in the uptake and quality of e-activities developed and used (Sheehy et al., 2006). Recommendations to "initiate a multilevel audit of teaching time and WAMs" (Tynan et al., 2012, p. 112) and then develop WAMs that incorporate TEL strategies are the way forward for initiating cultural change and exposing this hidden element of TEL-associated workload. Of course, this will only occur if all stakeholders in WAMs are brought to the table for real discourse regarding economic impacts of TEL, as recommended by Tynan et al. (2012) in their "Out of Hours" report.

\section{University financial support for workload allocations}

Coupled with a university's commitment to policy-level implementation of TEL is the need to provide financial allocation at different levels. Time and funding allocations that provide staff development opportunities and a commitment to providing "stable, reliable technology" (Clarke, 2011, p. 22) are both likely to have a positive impact on faculty workloads when recognised as professional requirements to providing good services to students. Successful university-wide uptake of blended learning has also been reported where alternative internal funding models have been shifted from student contact hours to student outcomes model (Clark, 2011).

\section{Proposed model for the incorporation of TEL into WAMs}


The difficulty with incorporating TEL into any workload model revolves around two key elements: implementer experience or competency and the nature of any given specific TEL initiative. The combination of these means that a broad scope of need exists that is not readily converted into a traditional notional hours assigned matrix. McNickle and Cameron (2003) discussed the need for such local workload negotiation models to account for the flexible load associated with flexible delivery. Thus, here we propose a model that will facilitate administrators to make informed decisions around specific needs and begin negotiated discussions regarding the more realistic impact of implementing TEL activities. The proposed model (Table 1)enables the ability to provide alerts for areas where additional support requirements may be appropriate. Thus, we propose the model not for definitive allocation of notional hours or point allocation but rather to facilitate real discussion associated with the impact on TEL strategies on academic workload-thereby providing an opportunity to strategically support TEL design, implementation and review processes and thus support academics at the coalface.

\section{Explanation of the model}

The model is designed with the intention that it is flexible and negotiable and can be built upon as new methodologies associated with TEL are developed or the context of a specific institution is applied. The examples provided below are given as common current TEL strategies used in higher education that inherently will change over time.

The three categories of novice (N), intermediate (I) and experienced (E) in no way reflect the teaching experience of an individual but are explanatory for the level of experience an academic has previously had with a particular type of TEL strategy type. A novice would be someone who had never previously implemented a specific type of TEL strategy before. An academic of intermediate experience has most likely implemented the strategies at least once or twice before. An experienced academic has been involved in multiple iterations of the strategy, possibly via multiple application contexts.

Table 1. Indication of potential necessity for additional workload associated with each stage of TEL strategy development relative to the academic experience or capacity.

\begin{tabular}{|l|c|c|c|c|c|c|c|c|c|c|c|c|c|}
\hline $\begin{array}{c}\text { Nature of TEL } \\
\text { Activity }\end{array}$ & \multicolumn{3}{|c|}{$\begin{array}{c}\text { Professional } \\
\text { Development }\end{array}$} & $\begin{array}{c}\text { Preparation } \\
\text { Time }\end{array}$ & \multicolumn{2}{|c|}{$\begin{array}{c}\text { Implementation } \\
\text { Time }\end{array}$} & \multicolumn{2}{|c|}{$\begin{array}{c}\text { Review/ } \\
\text { Reflection }\end{array}$} \\
\hline & N & I & E & N & I & E & N & I & E & N & I & E \\
\hline
\end{tabular}




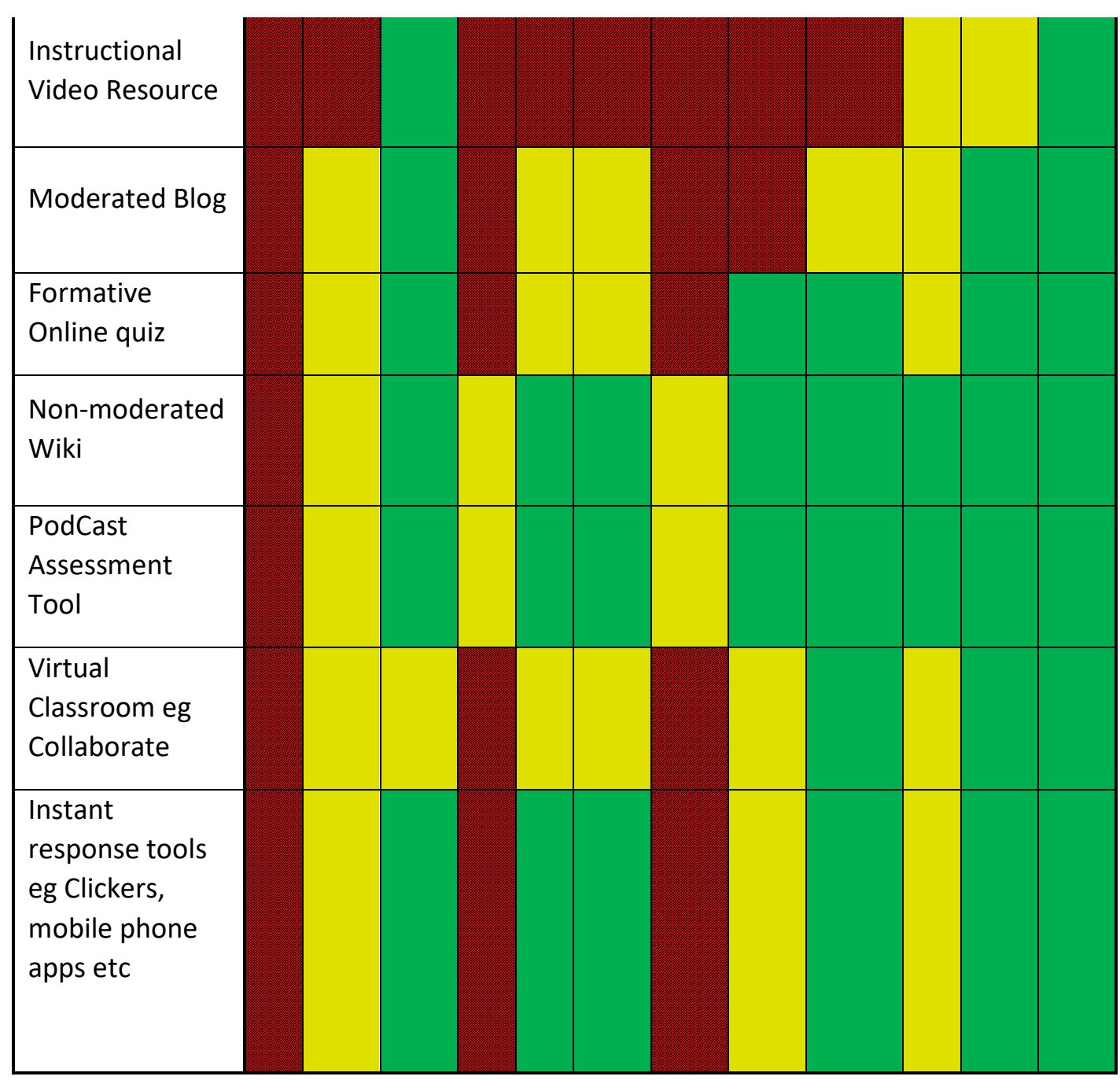

\begin{tabular}{|c|c|c|}
\hline Red & Yellow $\square$ & Green \\
\hline $\begin{array}{c}\text { Higher workload } \\
\text { requirement }\end{array}$ & $\begin{array}{c}\text { Moderate workload } \\
\text { requirement }\end{array}$ & $\begin{array}{c}\text { Lower workload } \\
\text { requirement }\end{array}$ \\
\hline
\end{tabular}

Note: Patterns indicates potential load expected over and above normal load allocation for specific tasks.

Stripes: Higher workload requirement. Dots: moderate workload requirement. Plain: lower workload requirement. $\mathrm{N}=$ novice; I = intermediate; $\mathrm{E}$ = experienced.

The colours/shading indicate the level of potential assistance that may be required to support the appropriate implementation of TEL strategies. This is with regards to both time required and actual work to be completed over and above the amount normally attributed to any alternate TEL strategy. Red (stripe) suggests that considerable additional time, yellow (spot) may require some time and green (no pattern) indicates that it is unlikely to require time over and above normal coursework load allocations. Many institutions have resources and support mechanisms that can be utilised if the need is identified; for example, grant schemes directed towards the implementation of TEL strategies, dedicated financial and time allocation support to attend professional development for a specific TEL 
that can then be fed back into an entire school, specialist support staff to address the technological challenges some TEL activities provide or additional allocation of resources or time for specific tasks such as assessment development (over and above normal allocations).

The model can be utilised on one of three ways: (a) It could be used to identify a single, specific need for an individual academic, such as professional development with regards to a specific TEL activity. Such that a case can be made to provide support in this area if the TEL aligns with strategic priorities, need for the TEL activity and the long-term pedagogical and technical benefits for students can also be proposed. (b) It could be utilised as a collective tool for an academic regarding the holistic view of a TEL strategy. Where multiple red (stripe) or yellow (spot) squares are found for specific activities, appropriate support throughout the entire process can be provided. The model provides a place to begin discussions on how the TEL will impact that particular academic's workload and how collectively strategies can be developed to support exacerbation of load. (c) It could also be used as a knowledge gathering tool for identifying skills within a school or institution for the purposes of peer mentoring and support. Although there is a burgeoning trend to establish TEL support units within institutions, those that exist struggle to meet demand given the rapid evolution of educational technologies. By establishing a rolling skills directory with regards to known TEL activities and level of experience, a school or faculty could help create a more collaborative network to up-skill all academic members.

Ultimately any proposal to implement TEL strategies requires justification for support mechanisms to be utilised that are in alignment with university-wide policy, are not reinventing the wheel and have identifiable, pedagogically sound benefits to optimise student learning outcomes. All of these should also comply with any strategically planned change to curriculum design, implementation or assessment strategies.

For any given TEL activity for an academic considered experienced in the technique, it may be that minimal training and limited preparation time may be required. Yet depending on the nature of that TEL activity, even an experienced academic may require significant implementation time allocation. Once managers have a general idea of how a TEL activity may impact an individual academic's workload, informed decisions around load allocation or the utilisation of additional resources, funding avenues or support staff can be made. In some cases, sufficient provision may fall under normal preparation, teaching and marking time. Some may not. What is critical is to ensure that high quality TEL offerings that are well aligned with pedagogical requirements and maintain academic standards are developed and that academic staff are appropriately supported to achieve these goals.

\section{Hypothetical case study exemplars of the impact of two TEL sources on academic workload: video production and formative assessment quizzes}


Two different skill level academics who might consider developing a video resource to support a course will require varying levels of support at different stages. Although most academics are probably familiar with the general scope of their university's basic LMS or virtual learning environment, gaining experience in the more technical elements and applications does take time. What could be the potential impact of time and workload for developing and implementing TEL resources with respect to training, preparation, implementation and review?

Table 2 presents a hypothetical exemplar of how the matrix might be utilised to determine the potential impact of TEL implementation on individual academic workloads.

For the exemplar on instructional video production (Table 2), when the matrix is applied for both the experience level and type of TEL activity proposed, it would appear that significant additional workload would need to be allocated for the preparation phase of developing video resources regardless of experience level. Looking to existing literature regarding previous use of the TEL activity can be helpful in providing evidence of the need to progress with the implementation despite the high workload required based on good pedagogical practice, recognised potential positive impact on student learning outcomes and well-planned instructional design. Use of the model would suggest that perhaps a funding source may be required (such as an internal university grant) to provide additional support for financial and workload concerns. Early identification of this source might enable

Table 2. Video resource production matrix exemplar. N (novice), I (intermediate) and E (experienced) refer to the level of experience and academic may previously had with a particular type of TEL. Colour/shading indicates potential load expected over and above normal load allocation for specific tasks.

\begin{tabular}{|l|l|l|l|l|l|l|l|l|l|l|l|l|}
\hline \multicolumn{2}{|c|}{$\begin{array}{c}\text { Professional } \\
\text { Development }\end{array}$} & \multicolumn{3}{c|}{ Preparation } & \multicolumn{3}{c|}{ Implementation } & \multicolumn{3}{c|}{ Review/ } \\
Improvement \\
\hline N & I & E & N & I & E & N & I & E & N & I & E \\
\hline
\end{tabular}

\begin{tabular}{|c|c|l|}
\hline Red & Yellow & Green \\
\hline Higher workload requirement & $\begin{array}{c}\text { Moderate workload } \\
\text { requirement }\end{array}$ & Lower workload requirement \\
\hline
\end{tabular}

Note: Patterns indicates potential load expected over and above normal load allocation for specific tasks.

Stripes: Higher workload requirement. Dots: moderate workload requirement. Plain: lower workload requirement. $\mathrm{N}=$ novice; I = intermediate; $\mathrm{E}$ = experienced. 
workload negotiation as part of creation such a TEL strategy. This type of discussion might also be able to facilitate negotiation of additional technical support or professional development around this specific type of TEL activity, provided sufficient alignment with the institution's strategic plans and learning design can also be accounted for. Thus, the model supports early identification of pivotal points that could impact the success of implementing such a TEL activity.

The podcast example shown in Table 3 is a much simpler one where the amount of training required to support student production of podcast materials may need minor initial professional development even for a novice. Implementation of a first or second iteration may be a little challenging, depending on what additional criteria were included if this was used for assessment (e.g., peer marking, rubric development, LMS capacity for hosting, copyright issues with external publishing or the use of copyright materials such as music). However, these are elements more associated with good curriculum design, and as such should not cause additional workload regardless of the inclusion of a TEL activity.

\section{Implications for enabling uptake of TEL by addressing hidden workload issue}

The "impact of blended learning is monumental, permanently changing students' interaction with higher education" (Matheos, 2010). It should be a transformative process, not merely a cut and paste from traditional models. Thus for institutions to remain competitive they will need to incorporate TEL. To achieve this successfully requires multi-tiered recognition of the potential impact of TEL from all areas of higher education.

Identification of the impact on academic workload associated with TEL does not occur in an insular environment; it significantly contributes to the teaching presence component of the COI model (Garrison et al., 2010), which overlaps with both social and cognitive presences to provide a student educational experience. The impact of the hidden and thus unaccounted for academic workload associated with TEL could put university educational programs at risk of poor student experience outcomes if ignored.

Development of relevant, well-aligned university policy and WAMs, timely staff professional development and continued support, acknowledgement and address of changes to academic workload that TEL can create, are critical. An institution-wide framework approach in both policy and funding models has the best chance for successful development and application of TEL approaches. It was recently recommended in the ALTC Good Practice Guide: Blended Learning (Partridge et al., 2011).

Table 3. Podcast for assessment matrix exemplar.

\begin{tabular}{|c|c|c|c|c|c|c|c|c|c|c|c|}
\hline \multicolumn{2}{|c|}{$\begin{array}{c}\text { Professional } \\
\text { Development }\end{array}$} & \multicolumn{3}{|c|}{ Preparation } & \multicolumn{3}{c|}{ Implementation } & \multicolumn{3}{c|}{$\begin{array}{c}\text { Review/ } \\
\text { Improvement }\end{array}$} \\
\hline $\mathrm{N}$ & $\mathrm{I}$ & $\mathrm{E}$ & $\mathrm{N}$ & $\mathrm{I}$ & $\mathrm{E}$ & $\mathrm{N}$ & $\mathrm{I}$ & $\mathrm{E}$ & $\mathrm{N}$ & $\mathrm{I}$ & $\mathrm{E}$ \\
\hline
\end{tabular}




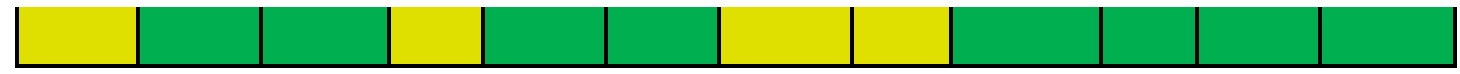

\begin{tabular}{|c|c|c|}
\hline Red & Yellow & Green \\
\hline $\begin{array}{c}\text { Higher workload } \\
\text { requirement }\end{array}$ & $\begin{array}{c}\text { Moderate workload } \\
\text { requirement }\end{array}$ & $\begin{array}{c}\text { Lower workload } \\
\text { requirement }\end{array}$ \\
\hline
\end{tabular}

Note: Patterns indicates potential load expected over and above normal load allocation for specific tasks.

Stripes: Higher workload requirement. Dots: moderate workload requirement. Plain: lower workload requirement. $\mathrm{N}=$ novice; $\mathrm{I}$ = intermediate; $\mathrm{E}$ = experienced.

Ultimately, it is important to remember that the provision of a flexible and engaging TEL environment that focuses on excellent student learning experiences and outcomes is paramount. However, recognition of the impact of fluid academic identity and concurrent sensitivity and realism associated with the needs of academic staff is equally important. This can be achieved by ensuring university-wide cultural accountability for the impact of the hidden barrier, academic workload allocations, to TEL in twenty-first century higher education. The model presented here can be utilised by individual academics, faculty executive and policy makers alike, and can be further developed by institutions to suit their own TEL strategies and activities to promote discussion regarding the hidden impact of workload allocations to the implementation of TEL in higher education.

\section{Disclosure statement}

No potential conflict of interest was reported by the authors.

\section{Notes on contributors}

Mary Sarah-Jane Gregory, MPhil, holds a fractional appointment at Griffith University and is known for her work on second-year student tertiary experiences and early adoption of TELs in the Biosciences. This unique combination provides her with an awareness of the impact TEL developments can have on student experiences and academic workloads.

Jason Michael Lodge, PhD, is a psychological scientist and research fellow at the Science of Learning Research Centre and Melbourne Centre for the Study of Higher Education, University of Melbourne. Jason's research concentrates on cognitive and emotional factors in learning, thinking and the development of expertise, particularly in digital learning environments.

\section{References}

Aldridge, S. (2013, March 20). 3 ways technology-enhanced courses benefit learners [Blog post]. The Online Learning Curve. Retrieved from http://www.learninghouse.com/blog/publishing/3-waystechnology-enhanced-courses-benefit-learners Anderson, C. (2012). Barriers and enablers to teachers' adoption of online teaching at an 
Australian university (Doctoral dissertation). Retrieved from

https://researchbank.rmit.edu.au/eserv/rmit:160215/Anderson.pdf

Australian Council for Educational Research. (2011). ACER Higher Education Update, 7.

Retrieved from http://www.tda.edu.au/cb_pages/files/ACER\%20Higher\%20Education\%20Update\%207.pdf

Barrett, L., \& Barrett, P. (2008). The management of academic workloads: Full report on

findings. London: Leadership Foundation for Higher Education. Retrieved from

http://www.research.salford.ac.uk/maw/cms/resources/uploads/File/Barrett\%20long\%20report\%20links\%

20final.pdf

Bates, T. (2000). Managing technological change: Strategies for college and university

leaders. San Francisco, CA: Jossey-Bass.

Bates, T. (2004). The promise and the myths of e-learning in post-secondary education. In

M. Castells (Ed.), The network society: A cross-cultural perspective (pp. 271-292).

Cheltenham: Edward Elgar. Retrieved from http://www.tonybates.ca/wp-

content/uploads/2008/07/castell4.pdf

Bates, T. (2005). Technology, e-learning and distance education. London: Routledge.

Bath, D., \& Bourke, J. (2010). Getting started with blended learning. Retrieved from

http://www.griffith.edu.au/_data/assets/pdf_file/0004/267178/Getting_started_with_blended_learning_guid e.pdf

Benson, V., Anderson, D., \& Ooms, A. (2011). Educators' perceptions, attitudes and practices:

Blended learning in business and management education. Research in Learning Technology, 19, $143-154$.

Retrieved from http://www.researchinlearningtechnology.net/index.php/rlt

Biggs, J., \& Collins, K. (1982). Evaluating the quality of learning: The SOLO taxonomy.

New York, NY: Academic Press.

Bleffert-Schmidt, A. (2011). The blended learning experience of community college students

(PhD dissertation). Available from ProQuest database. (Publication No. 3509552)

Boitshwarelo, B. (2009). Exploring blended learning for science teacher professional

development in an African context. International Review of Research in Open and Distance Learning, 10(4), 1-

19. Retrieved from http://www.irrodl.org/index.php/irrodl

Bredeson, P. (2003). The APC Summer Institute, 2003: A two-day workshop with ProfessorPaul Bredeson.

Retrieved from http://research.acer.edu.au/apc_monographs/12

Cavalli, E., Gnudi, A., Iovino, D., Lorenzi, A., \& Malvisi, L. (2007). Lecturer perception of

the effectiveness of blended learning and institutional support mechanisms. In A. Szücs \& I. Bø (Eds.),

Proceedings of European Distance and E-learning Network 2007 Conference, New Learning 2.0?-Emerging

digital territories - Developing continuities-New divides (pp. 1-6). Budapest: EDEN. Retrieved from

http://www.eden-online.org/system/files/Annual_2007_Naples_BOA.pdf

Chalmers, D. (2011). Progress and challenges to the recognition and reward of the Scholarship of Teaching in higher education. Higher Education Research and Development, 30,

25-38. doi:10.1080/07294360.2011.536970

Clark, B. (2011). Moving the technology into the AU/LBS Classroom Project: Blended delivery: 
A literature review. Ontario: Ministry of Training, Colleges and Universities.

Retrieved from http://www.hpedsb.on.ca/ec/elearning/documents/BeaClarkes-Blend edlearningreview.pdf

Cuban, L. (2001). Oversold and underused: Computers in the classroom. Cambridge: Harvard University Press.

Diaz, V., \& Brown, M. (2010). Blended learning: A report on the ELI focus session (ELI

Paper 2: 2010). Boulder, CO: EDUCAUSE Learning Initiative. Retrieved from net.edu cause.edu/ir/library/pdf/ELI3023.pdf

Dowdle. (2004). E-learning survey: Report on findings. York: Higher Education Academy.

Fleck, J. (2012). Blended learning and learning communities: Opportunities and challenges. Journal of Management Development, 31, 398-411. doi:10.1108/02621711211219059

Garrison, D. (2003). Blended approaches to teaching and learning: A position paper (Unpublished paper). Calgary: University of Calgary.

Garrison, D., Anderson, T., \& Archer, W. (2010). The first decade of the community of inquiry framework: A retrospective. The Internet and Higher Education, 13, 5-9.

doi:10.1016/j.iheduc.2009.10.003

González, C. (2010). What do university teachers think eLearning is good for in their teaching? Studies in Higher Education, 35, 61-78. doi:10.1080/03075070902874632

Goodyear, P., \& Ellis, R. (2008). University students' approaches to learning: Rethinking the place of technology. Distance Education, 29, 141-152. doi:10.1080/01587910802154947 Goodyear, P., \& Retalis, S. (2010). Technology enhanced learning: Design patterns and pattern languages. Rotterdam: Sense Publishers.

Gormally, C., Evans, M., \& Brickman, P. (2014). Feedback about teaching in higher ed: Neglected opportunities to promote change. CBE Life Sciences Education, 13, 187-199. doi:10.1187/cbe.13-12-0235

Gosper, M., McNeill, M., Phillips, R., Preston, G., Woo, K., \& Green, D. (2010). Web - based lecture technologies and learning and teaching: A study of change in four Australian universities. ALT-J Research in Learning Technology, 18, 251-263. doi:10.1080/ 09687769.2010 .529111

Graham, C., \& Dziuban, C. (2008). Blended learning environments. In J. M. Spector, M. D. Merril, J. V. Merrienboer, \& M. P. Driscoll (Eds.), Handbook of research on educational communications and technology (3rd ed., pp. 269-276). New York, NY: Lawrence Erlbaum. Retrieved from http://byu.academia.edu/CharlesRGraham/Papers/564026/ Blended_learning_environments Hartman, J., Dziuban, C., \& Moskal, P. (2000). Faculty satisfaction in ALNs: A dependent or independent variable? Journal of Asynchronous Learning Networks, 4, 155-179.

5 Retrieved from http://onlinelearningconsortium.org/read/journal-issues/ 
Hartman, J., \& Truman-Davis, B. (2001). The holy grail: Developing scalable and sustainable support solutions. In C. Barone, \& P. Hagner (Eds.), Educause leadership strategies: Vol 5. Technology-enhanced teaching and learning-Leading and supporting transformation on your campus (pp. 45-56). San Fransisco, CA: Jossey-Bass.

Harvey, L., \& Williams, J. (2010). Fifteen years of quality in higher education. Quality in Higher Education, 16, 3-36. doi:10.1080/13538321003679457

Henkel, M. (2005). Academic identity and autonomy in a changing policy environment. Higher Education, 49, 155-176. doi:10.1007/s10734-004-2919-1

Herrington, A., Schrape, J., Flintoff, K., Leaver, T., Molineux, M., \& O'Hare, S. (2010). A scholarship program for academic staff to develop exemplary online learning tasks. In C. Steel, M. Keppel, P. Gerbic, \& S. Housego (Eds.), Curriculum, technology \& transformation for an unknown future. Proceedings ascilite Sydney 2010 (pp. 423-427). Retrieved from http://ascilite.org.au/conferences/sydney10/procs/Herrington-concise.pdf Hugo, G. (2008). The demographic outlook for Australian universities' academic staff (Occasional Paper). Canberra: Council for Humanities, Arts and Social Sciences. James, R., Krause, K.-L., \& Jennings, C. (2010, October 1). The first year experience in Australian universities: Findings from 1994-2009. Canberra: Commonwealth of Australia. Retrieved from http://www.griffith.edu.au/_data/assets/pdf_file/0006/37491/FYERe port05.pdf

King, A. (1993). From sage on the stage to guide on the side. College Teaching, 41, 30-35. doi:10.1080/87567555.1993.9926781

Kirkwood, A., \& Price, L. (2014). Technology-enhanced learning and teaching in higher education: What is 'enhanced' and how do we know? A critical literature review. Learning, Media and Technology, 39, 6-36. doi:10.1080/17439884.2013.770404 Ko, S., \& Rossen, S. (2004). Teaching online: A practical guide. Boston, MA: Houghton Miffin.

Laurillard, D. (2007). Modelling benefits-oriented costs for technology enhanced learning. Higher Education, 54, 21-39. doi:org/10.1007/s10734-006-9044-2

Laurillard, D., Oliver, M., Wasson, B., \& Hoppe, U. (2009). Implementing technology-enhanced learning. In N. Balacheff, S. Ludvigsen, T. de Jong, A. Lazonder, S. Barnes, \& L. Montandon (Eds.), Technology-enhanced learning (pp. 289-306). Berlin: Springer Science+Business. doi:10.1007/978-1-4020-9827-7 17 Lazarsfeld Jensen, A., \& Morgan, K. (2009). The vanishing idea of a scholarly life: Workload calculations and the loss of academic integrity in Western Sydney. Australian Universities' Review, 51, 62-69. Retrieved from http://issuu.com/nteu/docs/aur_51-02 Matheos, K. (2010). Innovative practices research project (COHERE Report on Blended Learning). Manitoba: Collaboration for Online Higher Education and Research 
(COHERE). Retrieved from https://facultycommons.macewan.ca/wp-content/uploads/ REPORT-ON-BLENDED-LEARNING-FINAL1.pdf

McIntyre, S., Watson, K., \& Larsen, S. (2009). Strategies for large scale blended learning initiatives: Training, teaching and management. In E. Terry, A. Jefferies, \& A. Bracq (Eds.), Proceedings of the 4th International Blended Learning Conference (pp. 295-308). Hatfield: University of Hertfordshire. Retrieved from unsworks.unsw.edu.au/fapi/datastream/ unsworks:7750/SOURCE01

McNickle, C., \& Cameron, N. (2003). The impact of flexible delivery on human resource practices: Survey of TAFE managers. Adelaide: Australian National Training Authority. Means, B., Toyama, Y., Murphy, R., Bakia, M., \& Jones, K. (2009). Evaluation of evidencebased practices in online learning: A meta-analysis and review of online learning. Washington, DC: U.S. Department of Education.

Mellar, H., \& Jara, M. (2009). Quality assurance, enhancement and e-learning. In T. Mayes, D. Morrison, H. Hellar, P. Bullen, \& M. Oliver (Eds.), Transforming higher education through technology-enhanced learning (pp. 19-31). York: The Higher Education Academy.

Ocak, M. (2010). Blend or not to blend: A study investigating faculty members' perceptions of blended teaching. World Journal on Educational Technology, 2, 196-210. Retrieved from http://www.world-education-center.org/index.php/wjet/index

O'Connor, C., Mortimer, D., \& Bond, S. (2011). Blended learning: Issues, benefits and challenges. International Journal of Employment Studies, 19, 63-83. Retrieved from http:// iera.net.au/ijes_14.html

Oliver, M., \& Trigwell, K. (2005). Can ‘blended learning' be redeemed? E-Learning, 2, 17-26. doi:10.2304/elea.2005.2.1.17

Ooms, A. L., Burke, L., \& Linsey, T. (2008). Introducing e-developers to support a university's blended learning developments. ALT-J Research in Learning Technology, 16, 111-122. doi:10.3402/rlt.v16i2.10890

Paechter, M., Maier, B., \& Macher, D. (2010). Students' expectations of, and experiences in e-learning: Their relation to learning achievements and course satisfaction. Computers \& Education, 54, 222-229. doi:10.1016/j.compedu.2009.08.005

Partridge, H., Ponting, D., \& McCay, M. (2011). Good practice report: Blended learning. Sydney: Australian Learning \& Teaching Council. Perlmutter, D. (2011, July 29). Bridging the generational tech gap. The Chronicle of Higher Education (pp. B55-B58) Retrieved from http://www.hr.virginia.edu/uploads/docu ments/media/Chronicle_Rankings.pdf Picciano, A. G., \& Dziuban, C. (Eds.). (2007). Blended learning research perspectives. 
Needham, MA: Sloan Consortium.

Prensky, M. (2001). Digital natives, digital immigrants, part 1. On the Horizon, 9(5), 1-6. doi:10.1108/10748120110424816

Price, L., \& Kirkwood, A. (2010). Technology enhanced learning-Where's the evidence? In

C. H. Steel, M. J. Keppell, P.Gerbic, \& S. Housego (Eds.), Curriculum, technology \& transformation for an unknown future. Proceedings ascilite Sydney 2010 (pp. 772-782).

Retrieved from http://ascilite.org.au/conferences/sydney10/procs/Price-concise.pdf Quentin-Baxter, M., Kelly, J., Probert, S., MacMahon, C., \& Ferrell, G. (2008). A model for evidencing the benefits of technology-enhanced learning in higher education in the UK. In Hello! Where are you in the landscape of educational technology? Proceedings of ASCILITE 2008 (pp. 785-790). Retrieved from http://www.ascilite.org.au/conferences/ melbourne08/procs/quentin-baxter.pdf Quigley. (2011). Academic identity: A modern perspective. Educate, 11, 20-30. Retrieved from http://www.educatejournal.org/index.php/educate Reushle, S., McDonald, J., \& Postle, G. (2009). In T. Mayes, D. Morrison, H. Mellar, P. Bullen, \& M. Oliver (Eds.), Transforming higher education through technology-enhanced learning (pp. 58-71). York: The Higher Education Academy.

Rumble, G. (2011). Flexing costs and reflecting on methods. In L. Burge, C. Campbell Gibson, \& T. Gibson (Eds.), Flexible pedagogy, Flexible practice: Notes from the trenches of distance education (pp. 243-255). Athabasca: Athabasca University Press. Russell, T. L. (2001). The no significant difference phenomenon: A comparative research annotated bibliography on technology for distance education. Montgomery, AL: IDECC. Samarawickrema, G., \& Stacey, E. (2007). Adopting web - based learning and teaching: A case study in higher education. Distance Education, 28, 313-333. doi:10.1080/ 01587910701611344

Sappey, J., \& Relf, S. (2010). Digital technology education and its impact on traditional academic roles and practice. Journal of University Teaching \& Learning Practice, 7.

Retrieved from http://ro.uow.edu.au/jutlp/

Schneckenberg, D. (2009). Understanding the real barriers to technology-enhanced innovation in higher education. Educational Research, 51, 411-424. doi:org/10.1080/

00131880903354741

Sellani, R., \& Harrington, W. (2002). Addressing administrator/faculty conflict in an academic online environment. The Internet and Higher Education, 5, 131-145. doi:10.1016/ S1096-7516(02)00090-8

Sheehy, P., Marcus, G., Costa, F., \& Taylor, R. (2006). Implementing e-learning across a faculty: Factors that encourage uptake. Proceedings of the 23rd ASCILITE conference: 
Who's learning? Whose technology? (pp. 757-767). Sydney: Sydney University Press.

Retrieved from http://www.ascilite.org.au/conferences/sydney06/proceeding/pdf_papers/ p120.pdf

Singleton, D. (2012). The transition from traditional to blended on-campus learning experiences

(PhD dissertation). Available from ProQuest database. (Publication No. 3524006)

Starenko, M., Vignare, K., \& Humbert, J. (2007). Enhancing student interaction and sustaining faculty instructional innovations through blended learning. In A. G. Picciano \& C. D.

Dziuban (Eds.), Blended learning: Research perspectives (pp. 161-178). Needham, MA:

Sloan Consortium.

Tynan, B., Ryan, Y., Hinton, L., \& Lamont Mills, A. (2012). Out of hours: Final Report of the project e-Teaching leadership: Planning and implementing a benefits-oriented costs model for technology enhanced learning. Retrieved from http://www.olt.gov.au/resourceeteaching-leadership-planning-and-implementing-benefits-oriented-costs-model-technol ogy-en

Valenzuela, F.-R., Fisher, J., Whale, S., \& Adapa, S. (2013). Developing and evaluating social presence in the online learning environment. International Proceedings of Economics

Development \& Research, 60, 95-101. Retrieved from http://www.ipedr.com/

Vardi, I. (2009). The impacts of different types of workload allocation models on academic satisfaction and working life. Higher Education, 57, 499-508. doi:10.1007/s10734-008-

9159-8

Vaughan, N. (2007). Perspectives on blended learning in higher education. International Journal on E-Learning, 6, 81-94. Retrieved from http://www.editlib.org/j/IJEL/

Walker, R., Voce, J., \& Ahmed, J. (2012). 2012 survey of technology enhanced learning for higher education in the UK. Oxford: Universities and Colleges Information Systems Association. Retrieved from http://www.ucisa.ac.uk/groups/ssg/surveys.aspx Walker, R., Voce, J., Ahmed, J., Nicholls, J., Swift, E., Horrigan, S., \& Vincent, P. (2014). 2014 survey of technology enhanced learning: Case studies. Oxford: Universities and Colleges Information Systems Association. Retrieved from http://www.ucisa.ac. uk/groups/dsdg/asg/ /media/7BCB3F2FF0E141A79A66BC87DDB34A14.ashx Wallace, L., \& Young, J. (2010). Implementing blended learning: Policy implications for universities. Online Journal of Distance Learning Administration, 13. Retrieved from http:// www.westga.edu/ distance/ojdla/

Winter, R., \& O'Donohue, W. (2012). Understanding academic identity conflicts in the public university: Importance of work ideologies. In N. Brown, S. M. Jones, \& A. Adam (Eds.), Research and development in higher education: Connections in higher education (Vol. 35, pp. 340-351). Milperra: HERDSA. Retrieved from http://www.herdsa.org.au/wp-con tent/uploads/conference/2012/HERDSA_2012_Winter.pdf 